\title{
Effects of increased concentrations of chloride on the expression of Mn-SOD enzyme in tobacco
}

\author{
Akbar NORASTEHNIA ${ }^{1}$, Parvaneh SHEYDAEI ${ }^{2}$
}

Received May 15, 2016; accepted October 27, 2016.

Delo je prispelo 15. maja 2016, sprejeto 27. oktobra 2016.

\begin{abstract}
Chlorine is one of the ions contributing to salinity, despite being an essential micronutrient. $\mathrm{Cl}^{-}$absorption takes place more easily than other nutrients so, the toxic effects of chlorine on the growth has considered rather than its scarcity. Salt stress can ultimately leads to oxidative stress through ROS increase and antioxidant defense system is induced. Therefore, in this study the effect of different concentration of chlorine in irrigation water on the expression of manganese superoxide dismutase was investigated as an indicator of antioxidant defense system activation. Seedlings of tobacco were treated with different concentrations, i.e. 2, 4, $8 \mathrm{mM}$ of $\mathrm{CaCl}_{2}$. Evaluation of $\mathrm{Mn}-\mathrm{SOD}$ isoenzyme gene expression was performed using RT-qPCR (quantitative reverse transcription PCR) at $0,3,6$ and 12 hours after treatment. The results showed Mn-SOD gene transcription increased after $3 \mathrm{~h}$ treatment with $8 \mathrm{mM} \mathrm{CaCl}_{2}$ and peaked at 6 hours. Based on the observed changes, concentrations of calcium chloride greater than $8 \mathrm{mM}$ in water used for irrigation of tobacco causes stress that results in activation of antioxidant response.
\end{abstract}

Key words: chlorine; Mn-SOD; RT-qPCR (quantitative reverse transcription $\mathrm{PCR}$ ); salt stress

\section{IZVLEČEK}

\section{UČINKI POVEČANIH KONCENTRACIJ KLORIDA NA IZRAŽANJE GENA ZA ENCIM Mn-SOD PRI TOBAKU}

Klor je escencialno mikrohranilo, ki znantno prispeva $\mathrm{k}$ slanosti talne raztopine. Privzem $\mathrm{Cl}^{-}$poteka lažje kot drugih hranil zato so toksični učinki na rast pogostejši kot njegovo pomanjkanje. Solni stres vodi v oksidacijski stres preko tvorbe reaktivnih zvrsti kisika (ROS) in posledično $\mathrm{v}$ indukcijo antioksidativnega obrambnega sistema. $\mathrm{V}$ ta namen je bil $\mathrm{v}$ tej raziskavi preučevan učinek različnih koncentracij klora $\mathrm{v}$ vodi za namakanje na izražanje gena za mangan superoksid dizmutazo kot indikatorja aktivacije antioksidativnega sistema. Sadike tobaka so bile izpostavljene 2, 4, $8 \mathrm{mM}$ koncentracijam $\mathrm{CaCl}_{2}$. Ovrednotenje izražanja gena za izoencim Mn-SOD je bilo opravljeno z RT-qPCR metodo (kvantitativni PCR z reverzno transkripcijo) 0, 3, 6 in 12 ur po obravnavanju. Rezultati so pokazali, da se je transkripcija gena za Mn-SOD povečala po treh urah obravnavanja z $8 \mathrm{mM}$ $\mathrm{CaCl}_{2}$ in je dosegla višek po šestih urah. Na osnovi teh sprememb lahko zaključimo, da večje koncentracije kalcijevega klorida kot je $8 \mathrm{mM}$ v vodi za namakanje tobaka povzročijo stres, ki vodi $\mathrm{v}$ aktivacijo antioksidacijskega odziva.

Ključne besede: klor; Mn-SOD; kvantitativni PCR z reverzno transkripcijo; solni stres

\section{INTRODUCTION}

Abiotic stresses including drought, salinity, cooling, heating and heavy metal exposure are the major threats to plants and, thus to sustainable agriculture. Together, they decrease cereal production by more than $50 \%$ across the world (Tuteja, 2007). Salinity is one of the key stressors in the water or soil of arid and semi-arid regions and is able to limit growth and productivity of plants (Koca et al., 2007; Allakhverdiev et al., 2000). The rate of water evaporation and precipitation of salt are determinants of soil salinity. The process of water absorption by plant roots is impacted by high salinity via reduction in soil water osmotic potential, the outcome of which

\footnotetext{
1 University of Guilan, Faculty of Science, Department of Biology, Rasht, Iran, email: norasteh@ guilan.ac.ir

2 Same address as 1

This article is part of a Master thesis entitled »The effects of salt stress on gene expression of Mn-SOD enzyme of tobacco in hydroponic medium«, issued by Parvaneh Sheydaei, supervisor Assist. Prof. Akbar Norastehnia, Ph. D.
} 
is a physiological drought in plants (Mahajan and Tuteja, 2005). Although chloride ion is an essential micronutrient, it is also one of the ions contributing to salinity via osmotic stress induction, ion toxicity and nutrient imbalance. High concentrations of the ion adjoin to the active sites of many enzymes and disrupt cell function (Teakle and Tyerman, 2010). Salt stress, like other abiotic stresses, can lead to oxidative stress by the production of increased ROS (such as superoxide, hydrogen peroxide and hydroxyl radicals), which in turn leads to cell injuries due to the oxidation of lipids, proteins and nucleic acids (Esfandiari et al., 2007). Chloroplasts, mitochondria and peroxisomes are the major centers of ROS production (Fridovich, 1986). To reduce the effects of oxidative stress, plant cells have a complex antioxidant defense system. Superoxide dismutase is the first line of defense against ROS (Alscher and Hess, 1993). In eukaryotic cells SODs are the only enzymes that can catalyze the reduction of superoxide radicals to $\mathrm{H}_{2} \mathrm{O}_{2}$ and $\mathrm{O}_{2}$. SODs are metal-ubiquitin enzymes which exist in eukaryotic and prokaryotic cells with aerobic metabolism (Luis et al., 2002). Comparison of amino acid sequences of three isoforms of SOD indicate that Mn-SOD and FeSOD are ancient forms of the enzymes and probably came from the same ancestral enzyme. $\mathrm{Cu}-\mathrm{Zn}-\mathrm{SOD}$, on the other hand, is a eukaryotic enzyme that has no sequence homology to $\mathrm{Mn}$ SOD and Fe-SOD and must, therefore, have evolved separately. The fourth group of SOD isoforms, which exists in Streptomyces sp., is Ni-
SOD (II/III); $2 \mathrm{Ni}^{+}$are located in the active site of the enzyme (Bowler et al., 1992). Mn-SOD is located in mitochondria and peroxisomes. Studies show that the high production of Mn-SOD in mitochondria is associated with increased resistance to stress (Shah and Nahakpam, 2012). Many successful attempts have been made to produce transgenic plants with each of the three isoforms of the SOD enzymes (Faize et al. 2011). However, only in transgenic plants expressing introduced $\mathrm{Mn}$-SOD protection against stressinduced damage was manifested - e.g., as mitigation of biomass reduction and leaf damage (Samis et al., 2002). These findings are consistent also with numerous studies investigating cold stress which have linked Mn-SOD to the plants responses in pea (Palma et al., 1998, Sevilla et al., 1980), corn (Baum and Scandalios, 1981), pine (Streller et al., 1994) and tea (Vyas and Kumar, 2005). Although it seems clear that manganese superoxide dismutase is an essential enzyme for the elimination of free radicals in plant cells under environmental stress (Baek and Skinner, 2003), it is also able to enhance salt stress tolerance in transgenic Arabidopsis overexpressing Mn-SOD (Wang et al., 2004). Its role in plant cells has not been clearly identified under salt stress. We have therefore investigated the effect of increased concentrations of $\mathrm{CaCl}_{2}$ in irrigation water on the expression of manganese superoxide dismutase (Mn-SOD) in tobacco plants (Nicotiana tabacum L.) using the RT-qPCR method.

\section{MATERIALS AND METHODS}

\subsection{The plant cultivation in hydroponic condition and sampling}

Seeds of tobacco ('Coker 347') were hydroponically fed in Hoagland solution for 2 weeks and, after germination, were moved to $10 \mathrm{~cm}$ diameter pots filled with perlite. Seedlings were grown on a $16 \mathrm{~h}$ light, $8 \mathrm{~h}$ dark schedule, at $60-80 \%$ humidity, and at a temperature of $25-$ $30{ }^{\circ} \mathrm{C}$, with light intensity of $\sim 90 \mu \mathrm{mol}$ photons $\mathrm{m}^{-2}$ $\mathrm{s}^{-1}$ for two months. There are three vegetative growth phases in tobacco plants, including root development, fast growth phase and leaf ripening. Naturally, the fast growth phase is usually the most sensitive. Selected samples with highly similar vegetative growth in the fast growth phase ( 8 leaf stage, $70-80 \mathrm{~cm}$ tall) were treated for $0,3,6$ and 12 hours with concentrations of 2,4 and $8 \mathrm{mM} \mathrm{CaCl}_{2}$ before sampling. Leaf discs were prepared from young leaves (second and third leaves from above) at $0,3,6$ and 12 hours after treatment then transferred to liquid nitrogen and stored in a freezer at $-70{ }^{\circ} \mathrm{C}$.

\subsection{RNA extraction}

RNA was extracted from 2 leaf discs from the same plant for each replicate by grinding them in liquid nitrogen. All extraction procedures were performed using Accuzol buffer from BIONEER 
Company, in accordance with their instructions. Extracted RNA was dissolved in $50 \mu \mathrm{l}$ DEPCtreated water. Electrophoresis on $1 \%$ agarose gels and determination absorption of the band on the gel at 280/260 nm was used to evaluate the quality and concentration of the extracted RNA. RNA concentration in $\mu \mathrm{g} / \mu \mathrm{l}$ was calculated from the absorption at $260 \mathrm{~nm}$ using an extinction coefficient of $40 \mathrm{mM}^{-1} \mathrm{~cm}^{-1}$ and $1 \mu \mathrm{g}$ RNA was used for cDNA synthesis using the Accupower RT premix kit according to the instructions provided by the BIONEER Company.

\section{3 cDNA synthesis and Primer design}

$1 \mu \mathrm{g}$ of RNA mixed with $0.5 \mu \mathrm{g}$ Oligo (dT) primer and was placed at $70{ }^{\circ} \mathrm{C}$ for 5 min for primer annealing. The material was then transferred to micro-tubes containing AccuPower RT PreMix and brought to a final volume of $20 \mu \mathrm{l}$ with DEPC water. The resulting solution was then vortexed for a few seconds then incubated at $42{ }^{\circ} \mathrm{C}$ for approximately 60 minutes. Synthesized cDNA was then incubated again at $94{ }^{\circ} \mathrm{C}$ for 5 minutes and stored at $-20{ }^{\circ} \mathrm{C}$. PCR primers were designed to amplify Mn-SOD gene as a master gene and Ef-1a as reference gene and synthesized based on Oligo 7 software. Primers (Table 1) amplified a 155 base pair (bp) fragment of EF-1a gene cDNA, as well as a144 base pair (bp) cDNA fragment of the gene for Mn-SOD.

Table 1: The sequences of the primers used for Real-Time PCR Analysis

\begin{tabular}{|c|c|c|l|}
\hline Accession number & Putative function & Tm $\left.\mathbf{(}^{\mathbf{}} \mathbf{c}\right)$ & \multicolumn{1}{c|}{ Primer sequence $\left.\mathbf{( 5}^{\prime} \mathbf{}^{\prime} \mathbf{3}^{\prime}\right)$} \\
\hline BAC75399.1 & Superoxide dismutase & 57.6 & $\begin{array}{l}\text { F: CGACACTAACTTTGGCTCCCTAGA } \\
\text { R: GGTTCCTCTTCTGGGAATAGACGT }\end{array}$ \\
\hline D63396.1 & Ef-1a & 53.5 & $\begin{array}{l}\text { F: AAGCCCATGGTTGTTGAGAC } \\
\text { R: GTCAACGTTCTTGATAACAC }\end{array}$ \\
\hline
\end{tabular}

\subsection{RT-qPCR}

RT-qPCR reactions were performed to measure Mn-SOD gene expression in treated and control samples. The reaction mixture was prepared in $25 \mu 1$ volumes consisting of:

1) $12.5 \mu \mathrm{l}$ of Maxima ${ }^{\circledR} \mathrm{SYBR}$ Green/ROX qPCR Master Mix (2X) (Fermentas)

2) $3 \mu 1$ of Forward and Reverse Primer

3) $2.5 \mu 1$ of Template cDNA,

4) $7 \mu 1$ of Sterile distilled water

These reactions were performed for as three technical replicates of samples from three biological replicates to measure the expression of target genes. Expression of Ef-1a, a housekeeping gene, was measured for the standardization of the Real-time PCR reactions. After standardizing the data to the expression of the housekeeping gene, the amount of target gene (Mn-SOD) mRNA expression was determined using the comparative $\left(2^{-\Delta \Delta \mathrm{CT}}\right)$ method (Livak and Schmittgen, 2001). Statistical analysis was performed using One Way ANOVA and Duncan's multiple range test using the SPSS 18 software package and diagrams related to changes in gene expression were plotted in Excel.

\section{RESULTS}

As seen in Figure 1, RNA bands, later extracted, are visible as bright spots on a dark background of the gel. The quality of the RNA is very good, as indicated by the very clearly demarcated $18 \mathrm{~s}, 28 \mathrm{~s}$ and 5/8s rRNA bands and by the fact that the intensity of the 28s rRNA band is substantially greater than that of the other bands (Figure 1A). 

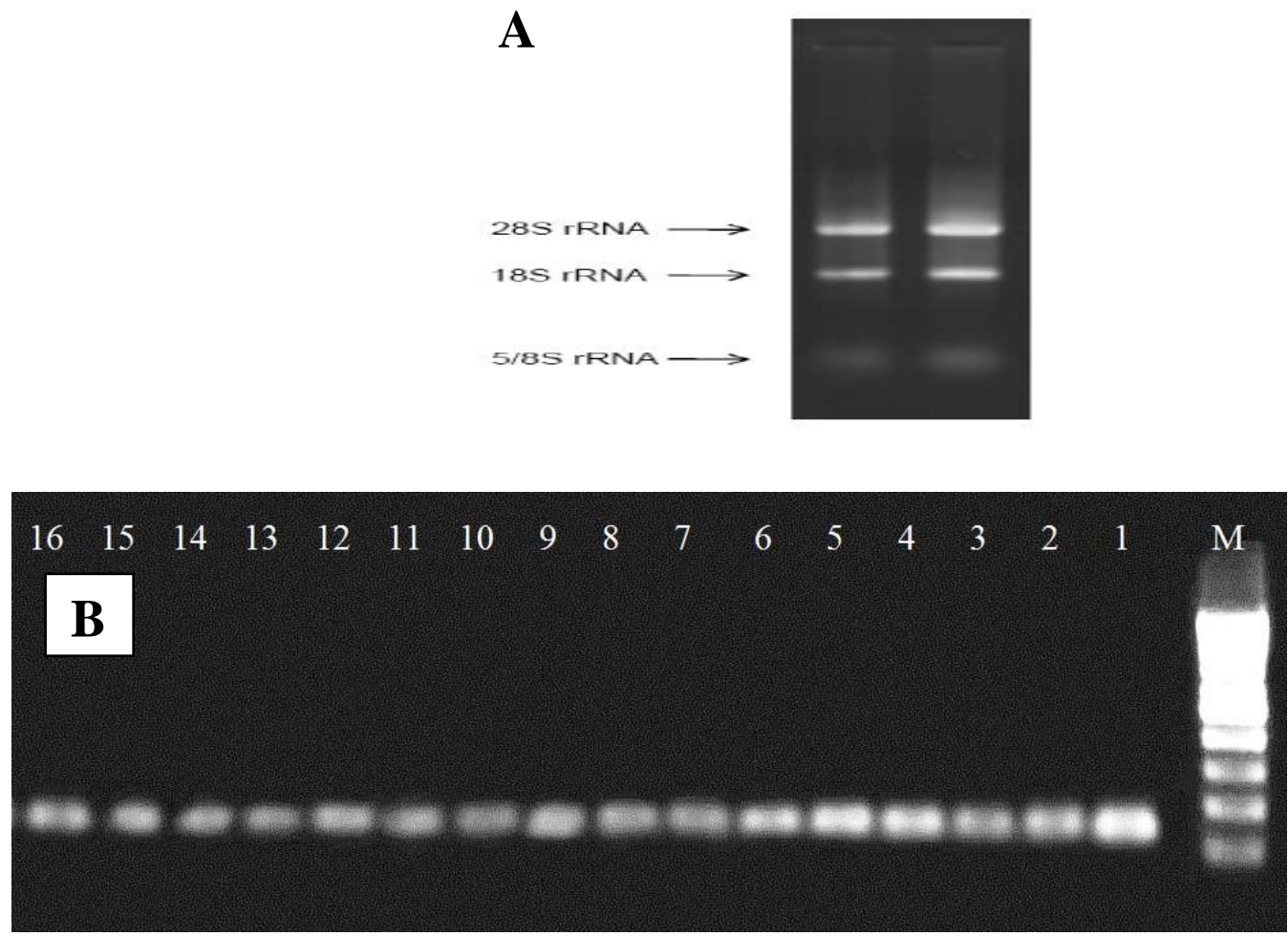

Figure 1: (A) Electrophoretic bands of the 18s and 28s RNAs related to the total RNA on $1 \%$ agarose gel extracted from tobacco leaves. The bands show proper quantity, lack of RNA degradation and no evidence of protein or DNA contamination in the samples. (B) $1 \%$ agarose gel electrophoresis for PCR products of the Mn-SOD gene in tobacco leaves. Bands 1 to 16 are related to $0(1-4), 3(5-8), 6(9-12)$ and 12 (13-16) hours after treatment with 0, 2, 4 and $8 \mathrm{mM} \mathrm{CaCl}_{2}$ treatments, respectively.

Fragment sizes of $144 \mathrm{bp}$ (Mn-SOD) and $155 \mathrm{bp}$ (Ef-1a) were amplified by the Real-Time PCR (Figure 1B). The measurement of manganese superoxide dismutase gene expression yielded different results in tobacco leaf at different hourly periods. Changes in the expression of the gene at 0 , 3,6 and 12 hours after treatment are shown in Figure 1B. According to the results, superoxide dismutase gene expression was the same in the all treatments at time of zero, immediately before chloride stress was initiated. There were also no significant differences between treated samples exposed to concentrations of 2,4 and $8 \mathrm{mM}$ calcium chloride. In other words, the Ef-1a gene is expressed in cells consistently in small amounts and remains in a base level under all conditions that we tested. The results for Mn-SOD were strikingly different. Three hours after the initiation of $\mathrm{Cl}^{-}$stress, a significant increase in $\mathrm{Mn}-\mathrm{SOD}$ mRNA expression was observed in plants treated with $8 \mathrm{mM}$ calcium chloride. In contrast, expression decreased in plants treated with the lower concentrations (Figure 2B). An extremely significant change was seen only at $8 \mathrm{mM}$ chloride relative to the control, six hours after initiation of the treatment (Figure 2C). By 12 hours exposure to $8 \mathrm{mM}$ chloride, Mn-SOD gene expression declined relative to levels after 3 hours exposure; Mn-SOD expression also remained constant in plants exposed to the lower concentrations (Figure 2D). 

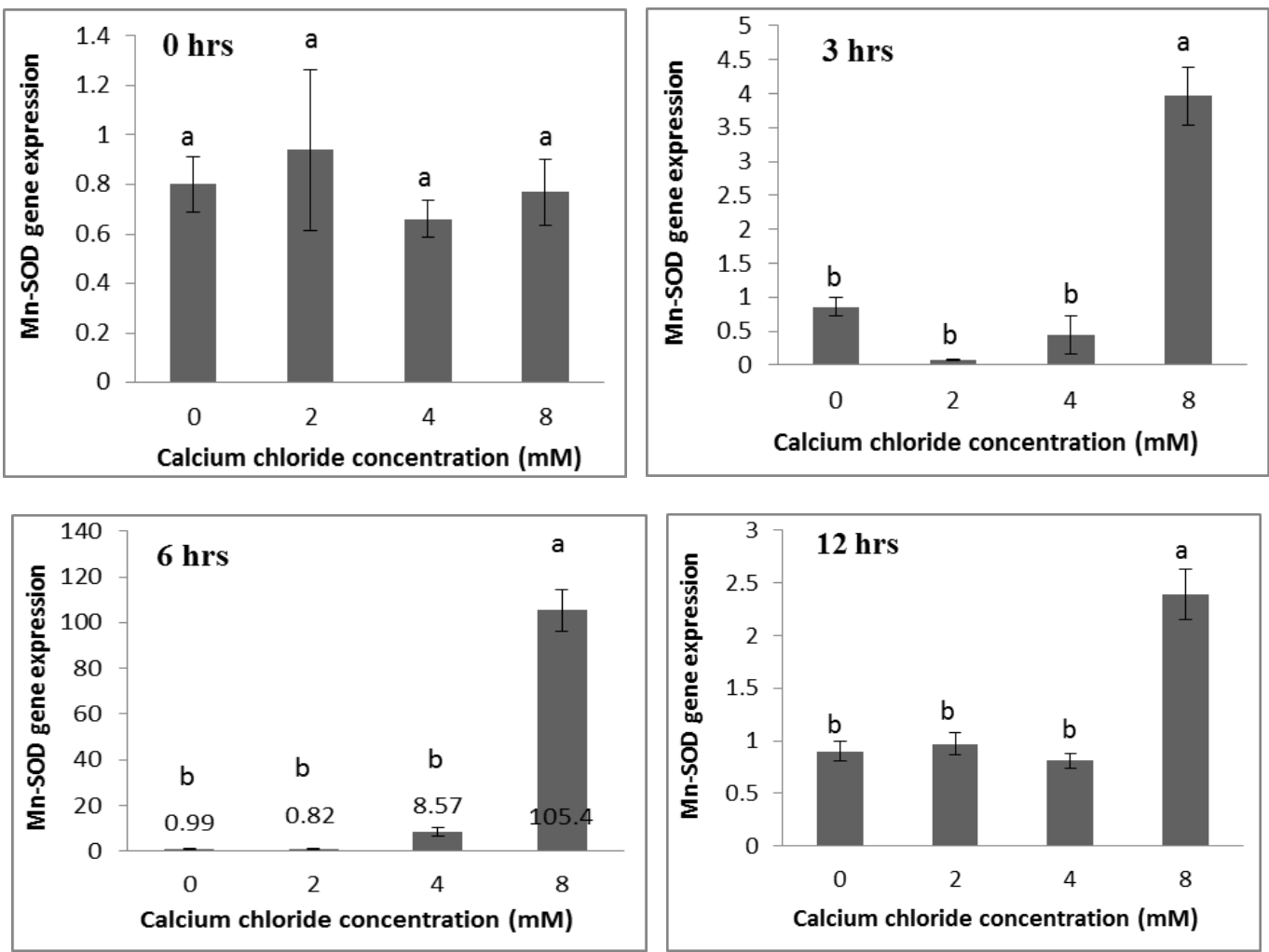

Figure 2: The expression of Mn-SOD at the time of zero, 3, 6 and 12 hours after stress at different concentration of calcium chloride. Data is average of three replicates \pm standard error (SE) respectively. Different letters indicate significant differences between treatments according to Duncan's test with $P<0.05$

\section{DISCUSSION}

Research has shown that the expression of various proteins is different under stress. In many plants, expression of some logically relevant soluble proteins, such as antioxidant enzymes, significantly increase or diminish in response to stress. Salinity also reduces synthesis of some proteins in certain plants and increases the hydrolysis of those proteins, leading to increasing of free amino acids (Kozlowski, 1997). According to the research conducted by Brou et al. (2007), superoxide dimutases are among several enzimes whose gene expression is upregulated in response to stress. This enzyme has multiple isoforms and differing expression can be seen among the isoforms in response to stress conditions. Therefore, these enzymes have been called biochemical markers for oxidative stress (Brou et al., 2007). In this study, increasing of expression of Mn-SOD was observed to be dependent on calcium chloride concentration and to the length of exposure of the plant to that stressor. While, as was noted in the results section, stressing the tobacco plants with 2 and $4 \mathrm{mM}$ calcium chloride did not cause significant changes in the expression of MnSOD. This is not entirely surprising, since it has been reported that concentrations of about $1 \mathrm{mM}$ are optimal for tobacco seedling growth (Norastehnia et al., 2014). In contrast, $8 \mathrm{mM}$ calcium chloride resulted in a strong stress response, as indicated by the dramatic increase in the expression of Mn-SOD. This very different response, extending for at least 12 hours, of increased expression of Mn-SOD indicates that chloride at this concentration is stressful to the plants. From the evidence our study has obtained, it can be suggested that Mn-SOD gene expression, like many of the genes involved in stress tolerance in plants, has a biphasic function. Basal gene expression is low. Upon exposure to $\mathrm{Cl}^{-}$stress, like other stresses, a rapid and significant increase occurs in gene expression (Sohani et al., 2009). This increase in the expression of Mn-SOD was similar to that also observed in other short-term oxidative stress studies, whereas long-term 
oxidative stress has been shown to reduce MnSOD expression, resulting in the accumulation of $\mathrm{O}_{2}^{-}$- particularly in chloroplasts and mitochondria (Liu and Huang, 2000). This decrease in the activity of an isoform of antioxidant enzymes alone does not indicate an inability of the plant to cope with stressful situations. There are many other enzymes that may also be involved in stress response. However, that is outside the scope of this particular study, but very relevant. Different isoforms of an enzyme, even, often exhibit their maximum activities in differing conditions or over differing time frames (Brou et al., 2007).

As was observed in the research of Brou et al. (2007), there are three isoforms of SOD in beans, including $\mathrm{Mn}$-SOD, Fe-SOD $\mathrm{Cu} / \mathrm{Zn}$-SOD; in drought stress conditions their intensities and time frames of action are quite different. While MnSOD and Fe-SOD expression increases during stress, the activity of $\mathrm{Cu} / \mathrm{Zn}-\mathrm{SOD}$ is reduced. Other studies have shown that in Pisum sativum L., increased expression of Mn-SOD occurs within 2-
96 hours of oxidative stress (Malecka et al., 2012). Many other researchers such as studying wheat (Keunen et al., 2011) and Brassica napus L. (Basu et al., 2001), have shown that increased expression of Mn-SOD is a good indicator of stress. Based on these studies, it can be said that plants deal with stress via increased expression and activity of antioxidant enzymes. That said, the specific type of stress, stress intensity and stress period has significantly different effects on gene behavior and impacts on the expression of many different proteins. Since, the first line of defense against reactive oxygen species are the superoxide dismutase (SOD), increasing the amount of SOD under stress can be considered as an indicator for the formation of oxidative stress. Therefore, that $\mathrm{Mn}-\mathrm{SOD}$ expression is increased under stress from concentrations of chlorine more than $4 \mathrm{mM}$ strongly indicates that oxidative stress is induced by excess chloride in tobacco plants. Future work to determine the mechanism by which this oxidative stress is generated will be of great interest.

\section{CONCLUSION}

According to this study seems stressing the tobacco plants with 2 and $4 \mathrm{mM}$ calcium chloride did not cause significant changes in the expression of Mn-SOD, while the concentration of $8 \mathrm{mM}$ calcium chloride acts as a severe stress for samples, so that the expression of Mn-SOD significantly increase. Irrespective of the impact of stress on expression of $\mathrm{Mn}-\mathrm{SOD}$, it can be expected that $8 \mathrm{mM}$ concentration of chlorine, is in the critical range in irrigation water for tobacco plants.

\section{REFERENCES}

Allakhverdiev, S.I., Sakamoto, A., Nishiyama, Y., Inaba, M., Murata, N. 2000. Ionic and osmotic effects of $\mathrm{NaCl}$-induced in activation of photosystems I and II in Synechococcus sp. Plant Physiol, 123: 1047-1056. doi:10.1104/pp.123.3.1047

Alscher, R.G., Hess, J.L. 1993. Antioxidants in higher plants, Boca Raton, FL. CRC press

Baek, K.H., Skinner, D.Z. 2003. Alteration of antioxidant enzyme gene expression during cold acclimation of near-isogenic wheat lines. Plant Sci. 165: 1221-1227. doi:10.1016/S01689452(03)00329-7

Basu, U., Good, A., Taylor, G. 2001. Transgenic Brassica napus plants overexpressing aluminium-induced mitochondrial manganese superoxide dismutase cDNA are resistant to aluminium. Plant Cell Environ. 24: 1278-1269. doi:10.1046/j.0016-8025.2001.00783.x

Baum, J.A., Scandalios, J.G. 1981. Isolation and characterization of the cytosolic and mitochondrial superoxide dismutases of maize. Arch Biochem Biophys, 206: 249-264. doi:10.1016/00039861(81)90089-8

Bowler, C., Montagu, M.V., Inze, D. 1992. Superoxide dismutase and stress tolerance. Annu Rev Plant Biol. 43: 83-116. doi:10.1146/annurev.pp.43.060192.000503

Brou, YC., Zézé, A., Diouf, O., Eyletters, M. 2007. Water stress induces overexpression of superoxide 
dismutases that contribute to the protection of cowpea plants against oxidative stress. Afr J Biotech. 6: 1982-1986. doi:10.5897/AJB2007.0002303

Esfandiari, E., Shakiba, M.R., Mahboob, S.A., Alyari, H., Toorchi, M. 2007. Water stress, antioxidant enzyme activity and lipid peroxidation in wheat seedling. J Food Agric Environ. 5: 149.

Faize, M., Burgos, L., Faize, L., Piqueras, A., Nicolas, E., Barba-Espin, G., Clemente-Moreno, M. et al. 2011. Involvement of cytosolic ascorbate peroxidase and $\mathrm{Cu} / \mathrm{Zn}$-superoxide dismutase for improved tolerance against drought stress. J Exp Bot. 62: 2599-613. doi:10.1093/jxb/erq432

Fridovich, I. 1986. Superoxide dismutases. Adv Enzymol RAMB, 58: 61-97. doi:10.1146/annurev.bi.44.070175.001051

Keunen, E., Remans, T., Bohler, S., Vangronsveld, J., Cuypers, A. 2011. Metal-induced oxidative stress and plant mitochondria. Int J Mol Sci. 12: 68946918. doi:10.3390/ijms12106894

Koca, H., Bor, M., Özdemir, F., Türkan, İ. 2007. The effect of salt stress on lipid peroxidation, antioxidative enzymes and proline content of sesame cultivars. Environ Exp Bot. 60: 344-351. doi:10.1016/j.envexpbot.2006.12.005

Kozlowski, T.T. 1997. Responses of woody plants to flooding and salinity. Tree Physiol Monograph. 1: 1-29. doi:10.1093/treephys/17.7.490

Liu, X., Huang, B. 2000. Heat stress injury in relation to membrane lipid peroxidation in creeping bentgrass. Crop Sci. 40: 503-510. doi:10.1093/treephys/17.7.490

Livak, K.J., Schmittgen, T.D. 2001. Analysis of relative gene expression data using real-time quantitative PCR and the 2- $\triangle \Delta C T$ method. Method. 25: 402408. doi:10.1006/meth.2001.1262

Luis, A., Corpas, F.J., Sandalio, L.M., Palma, J.M., Gómez, M., Barroso, J.B. 2002. Reactive oxygen species, antioxidant systems and nitric oxide in peroxisomes. J Exp Bot, 53: 1255-1272. doi:10.1093/jexbot/53.372.1255

Mahajan, S., Tuteja, N. 2005. Cold, salinity and drought stresses: an overview. Arch Biochem Biophys, 444: 139-158. doi:10.1016/j.abb.2005.10.018

Malecka, A., Piechalak, A. Mensinger, A., Hanc, A., Barałkiewicz, D., Tomaszewska, B. 2012. Antioxidative defense system in Pisum sativum roots exposed to heavy metals $(\mathrm{Pb}, \mathrm{Cu}, \mathrm{Cd}, \mathrm{Zn})$. Pol J Environ Stud. 21: 1721-1730.
Norastehnia, A., Niazazari, M., Sarmad, J., Rassa, M. 2014. Effects of chloride salinity on non-enzymatic antioxidant activity, proline and malondialdehyde content in three flue-cured cultivars of tobacco. J. Plant Develop. 21: 75-82.

Palma, J.M., López-Huertas, E., Corpas, F.J., Sandalio, L.M., Gómez, M., Del Río, L.A. 1998. Peroxisomal manganese superoxide dismutase: purification and properties of the isozyme from pea leaves. Physiol Plantarum. 104: 720-726. doi:10.1034/j.13993054.1998.1040429.x

Samis, K., Bowley, S., McKersie, B. 2002. Pyramiding Mn-superoxide dismutase transgenes to improve persistence and biomass production in alfalfa. J Exp Bot. 53: 1343-1350. doi:10.1093/jexbot/53.372.1343

Sevilla, F., Lopez-Gorge, J., Gomez, M., Del Rio, L. 1980. Manganese superoxide dismutase from a higher plant. Planta. 150: 153-157. doi:10.1007/BF00582359

Shah, K., Nahakpam, S. 2012. Heat exposure alters the expression of SOD, POD, APX and CAT isozymes and mitigates low cadmium toxicity in seedlings of sensitive and tolerant rice cultivars. Plant Physiol Biochem. 57: 106-113. doi:10.1016/j.plaphy.2012.05.007

Sohani, M, Schenk, P. Schultz, C.J., Schmidt, O. 2009. Phylogenetic and transcriptional analysis of a strictosidine synthase-like gene family in Arabidopsis thaliana reveals involvement in plant defence responses. Plant Biology. 11: 105-117. doi:10.1111/j.1438-8677.2008.00139.x

Streller, S., Krömer, S., Wingsle, G., 1994. Isolation and purification of mitochondrial Mn-superoxide dismutase from the gymnosperm Pinus sylvestris L. Plant Cell Physiol. 35: 859-867.

Teakle, N.L. and Tyerman, S.D. 2010. Mechanisms of Cl-transport contributing to salt tolerance. Plant Cell Environ. 33: 566-589. doi:10.1111/j.13653040.2009.02060.x

Tuteja, N. 2007. Mechanisms of high salinity tolerance in plants. Method Enzymol. 428: 419-438. doI:10.1016/S0076-6879(07)28024-3

Wang, Y., Ying, Y., Chen, J. and Wang, X. 2004. Transgenic Arabidopsis overexpressing Mn-SOD enhanced salt-tolerance. Plant Sci. 167: 671-677. doi:10.1016/j.plantsci.2004.03.032

Vyas, D., Kumar, S. 2005. Purification and partial characterization of a low temperature responsive Mn-SOD from tea (Camellia sinensis (L.) O. Kuntze). Biochem Bioph Res Co. 329: 831-838. doi:10.1016/j.bbrc.2005.02.051 